University of Louisville

ThinkIR: The University of Louisville's Institutional Repository

$5-2013$

\title{
Handling a social threat : the fate of women beyond Victorian societal definition.
}

Alexandra Clifton

University of Louisville

Follow this and additional works at: https://ir.library.louisville.edu/honors

Part of the Feminist, Gender, and Sexuality Studies Commons, and the Literature in English, British Isles Commons

\section{Recommended Citation}

Clifton, Alexandra, "Handling a social threat : the fate of women beyond Victorian societal definition." (2013). College of Arts \& Sciences Senior Honors Theses. Paper 10.

http://doi.org/10.18297/honors/10

This Senior Honors Thesis is brought to you for free and open access by the College of Arts \& Sciences at ThinkIR: The University of Louisville's Institutional Repository. It has been accepted for inclusion in College of Arts \& Sciences Senior Honors Theses by an authorized administrator of ThinkIR: The University of Louisville's Institutional Repository. This title appears here courtesy of the author, who has retained all other copyrights. For more information, please contact thinkir@louisville.edu. 
Handling A Social Threat: The Fate of Women Beyond Victorian Societal Definition

By

\author{
Alexandra Clifton
}

Submitted in partial fulfillment of the requirements

for Graduation (summa or magna) cum laude

and

for Graduation with Honors from the Department of English (if pertinent)

University of Louisville

March 2013

"Yet is it now my chosen task

To sing her worth as Maid and Wife;

Nor happier post than this I ask, 
To live her laureate all my life."

- "The Angel in the House," Coventry Patmore

So states Coventry Patmore's famed poem regarding an ideal few Victorian women could emulate, the subservient "Angel of the House" that Virginia Woolf wished she could "grab the angel by the throat" and destroy. For decades, the Angel was the accepted notion as to how women should and must behave, guardians of the domestic sphere that were extolled solely for their virtues as wives and mothers. Should a middle- or upper-class woman want any other fate, she would be thought mad or unnatural for not matching up to society's expectations. Such Victorian methods of thinking are now considered antiquated. The term "Victorian" is, in some ways, used as an insult: "Victorian” technology is outdated and clunky, "Victorian” morals prudish and hypocritical. Likewise, if gender roles are described as "Victorian," they appear to subscribe to traditional gender ideologies, with the men being the powerful, strong, and intelligent breadwinners of the family and the women as weak, feeble, domesticated caretakers. However, like all stereotypes, there is more complexity to Victorian gender roles than meets the eye.

Victorian men and women had to live and act by unwritten social codes, dictated by class and gender. Men were meant to participate actively in society; they were the "nobler sex" and, as a result, had the societal freedom to pursue their own interests with little criticism. Particularly in middle- and upper-class households, men had access to a wide education in everything from languages to hard sciences, could work in whatever profession they chose, could travel around the world as they pleased, and exerted political and economic rights over their female peers. Men could claim their wives' property as their own, or even claim their wives as their own property. Although a powerful woman ruled over the United Kingdom through most of the nineteenth century, men still held most of the political and social power. 
In contrast, women had to walk a fine line in their gender performance. Societal expectations encouraged them to be selfless domestic caretakers while relinquishing control over their lives to the men around them, be they husbands, fathers, or brothers. Writing in 1865, William Acton claimed that "love of home, children and domestic duties are the only passions women feel” (qtd. in Picard 322); indeed, it was believed that women could (or should) care about nothing more in their lives. Didactic novels and magazines guided a woman into becoming "professional domestic women" or "household fairies" that taught her to be a lady, as if it were a career (Rowbotham 15). Any deviance from this model was deemed unnatural, the woman a villain; if a woman asserted too much self-control over her life, even if she were acting the part of a good wife or good Victorian woman, she could be ostracized for acting too masculine. Not only was it thought unnatural, but it was also nearly impossible for Victorian middle-class women to escape the fate of marriage. It was also illegal for a woman to divorce her husband unless she could prove he had committed adultery and "incest, buggery, bestiality, cruelty or rape” (Picard 324); unless substantial evidence mounted up against the man, the woman had no power to escape her marriage. She was trapped, forced to take care of the house and children, toiling away as a beloved domestic goddess. Some women publicly encouraged others to embrace their roles; Sarah Stickney Ellis wrote that women's gift was the dignity of “moral greatness” (1585).

While many women in Victorian novels played into conventional notions of proper femininity, acting docile, pathetic, and sweet—-think Amy Dorrit in Charles Dickens' Little Dorrit or Laura Fairlie in Wilkie Collins' The Woman in White—some characters did not fit this role perfectly. They enacted some accepted traits of Victorian femininity, as beautiful women eternally devoted to their lovers, but flouted other conventions. More importantly, they also had 
certain "masculine" qualities about them: this is not to say that they were "butch" or "mannish," but that these women exhibited qualities normally found only in male characters of the time, showing intelligence and reason. They became fully-fleshed characters that did not rehash tired stereotypes of how women should or should not act.

In my view, this is especially true of the female protagonists of Mary Elizabeth Braddon’s Lady Audley’s Secret and H. Rider Haggard's She. Both Lady Lucy Audley ${ }^{1}$ and Ayesha, She-Who-Must-Be-Obeyed, reflect aspects of accepted Victorian feminine behaviour. Yet each woman also diverges from this prescribed role, embodying typically masculine behaviours and independence in addition to their uber-feminine qualities. The ultimate downfalls of both Lady Audley and Ayesha are brought about due to their transgressive and non-normative behaviours, and their stories serve as guides for the Victorian reading public: they became examples of how women should not act. I intend to compare Lady Audley and Ayesha with the approved male protagonists in their respective novels, directly contrasting Lady Audley with her nephew, Robert Audley, and Ayesha with the English explorer Ludwig Horace Holly. By proving that these women act not only as "ideal women" but also echo the actions of the "ideal men” of each novel, I hope to show that this synthesis requires their respective demises.

\section{Gaps in the scholarship}

A number of critics have discussed gender dynamics in both of these works, although not in the ways I wish to examine. I intend to show that Lady Audley and Ayesha's characteristics of accepted masculine and feminine behaviour make them "dangerous.” While critics have claimed these characters exhibit unconventional gender behaviour, none have emphasised how these characters embody both characteristics--they tend to focus on one or the other.

\footnotetext{
${ }^{1}$ Throughout the text, Lady Audley is referred to as Lucy Graham, her adopted disguise when she meets and marries Sir Michael Audley, as well as Helen Maldon, her identity as a wife to George Talboys. For simplicity's sake, I will tend towards calling her Lady Audley or Lucy Audley, unless an issue regarding her name comes up.
} 
A wealth of work has been done regarding femininity in Lady Audley's Secret, with some emphasizing the theatrical nature of Lucy Audley’s behavior. Lynn Voskuil claims that Lady Audley plays up her feminine side, especially in male-dominated contexts. She acts emotionally, like a child, to get her way, thus forcing her new husband to bow down to her will. Her childlike "innocence" arises no suspicion from the conventional figures of masculinity in the novel, such as Sir Michael Audley and George Talboys, yet causes great concern for Robert Audley. However, acting like an emotional child does not render her reasoning capabilities non-existent; rather, Lucy Audley becomes more “dangerous” for a Victorian audience because she is able to link together the "reasonable" (the traditionally male trait) with her emotional response, as she works to improve her life.

Other critics have made much of Lady Audley's feminine appearance; indeed, she becomes the archetype of the "blue-eyed wax doll” villainess, one who outwardly embodies acceptable femininity and does not cause a stir due to her childlike behavior. However, critics neglect to connect or comment on the "dangerous" combination of masculine and feminine aspects of Lady Audley's character. She is not a Victorian villain simply because she looks like a cherubic angel and yet her actions do not match, but because her looks and some aspects of her personality play into idealised notions of femininity whilst her actions mimic those of men. Critics such as Jennifer Hedgecock characterise Lady Audley as a femme fatale due to her beautiful looks that "put [her] victims off-guard" (118) while she contemplates her next move. While Hedgecock's reading is useful, she does not gender "reason" as a masculine trait as Braddon presents it, and neglects to mention how Lady Audley's actions mirror those of the males within the novel. 
Other work regarding Lady Audley’s Secret and gender subversion draws attention to how weak men are compared to the assertive women around them. Herbert Klein argues this role-reversal, stating that men are "in much greater danger from their sentimental feelings than women” (162). Klein's point is that the men in Lady Audley's Secret are just as susceptible (if not more) to emotional excesses than women in Victorian fiction, and that the women in the work—particularly Lady Audley—are far more assertively independent and rational. Klein does not discuss reason and emotion in depth, and neglects to comment on the fact that Lady Audley emulates both Robert Audley and George Talboys’ actions_-independently seeking her own way—and yet is punished for it. Natalie and Ronald A. Schroeder discuss a similar genderreversal that sets Lady Audley in opposition against her her former and current husbands, George and Sir Michael. They describe Lady Audley’s initial search for a husband as a "vocation” (30), comparing her pragmatic approach to marriage to a real job that a man would hold. They also note how George’s independence is linked to his male privilege: he can leave his wife, make his fortune in Australia, and refashion himself with little harm done to his social standing (35). Helen Talboys attempts the same thing after her husband leaves, changing her name to Lucy Graham and seeking a new husband, yet she is presented as deviant. While the Schroeders compare Lucy more with her husbands than they do with Robert, as I intend to-viewing the mature Robert as the acceptable version of Victorian masculinity - the points emphasise how, even though Lady Audley acts in many of the same ways that the men of the novel do, she is ultimately censured for her actions because they transgress prescribed gender behaviors.

While there is less critical work written on She-scholars appear to write more substantially on texts such as King Solomon's Mines - there is still an engaged critical conversation regarding what role Ayesha plays. Patricia Murphy argues that the gender politics 
of She are constructed to reinforce gender binaries, perpetually privileging the masculine elements over the female ones_- "good and evil, love and hate, sweet and bitter, man and woman" (Time 33). While it is important to note the existence of such binaries, especially since Victorian notions of gender were very much either/or, Ayesha is important because her power comes from refusing to fit comfortably within a binary—not either/or, but both/and. Several critics, including Rebecca Stott and Gerald Monsman, view Ayesha as a femme fatale: while it is a legitimate interpretation of her intoxicating femininity, I wish to show that it is only one part of Ayesha. Categorizing Ayesha solely as a femme fatale ignores her "masculine” behavior, such as her wide-reaching intelligence and desire to increase her power. Others, such as Murphy, read Ayesha as an admonition to the "New Woman" of the late nineteenth century (“Gendering” 747). The New Woman obtained some education and made her own living; while she did not necessarily hack into traditionally middle-class male jobs like doctors and lawyers, she was allowed some independence. Ayesha's similarities to the New Woman—and her eventual downfall based on her independent behaviour - underline the patriarchal Victorian fear that women would become uncontrollable and unconfined, possibly even overthrowing patriarchal rule.

Some critics briefly discuss Ayesha’s synthesis of traditional masculine and feminine characteristics. Norman Etherington observes that, in Haggard's works, there is a distinct theme of "role reversal in male-female relationships," where "women are cast as rulers and high priests” (78). He claims that Ayesha's “fatal combination of beauty and brains” connote "associations with powers of darkness" (79), but does not back up this claim with substantial evidence. Although he concludes that, while Haggard's "good women” are not lacking in brains, they "modestly and deliberately refrain from unleashing the full force of their physical and 
mental faculties” (81), due to Haggard's own reservations regarding women, stating that he felt "it was immoral for women to use their brains as men used their brains and to pursue power as men pursued power" (Etherington 86; emphasis mine). While Etherington problematically draws upon Haggard's biographical background to analyse his texts, his point remains valid: Victorian men feared that women would eventually pursue power as they did. I aim to expand upon Etherington's ideas, that part of the danger surrounding Ayesha and Lucy Audley is due to their willingness to use their brains and pursue power as men would while still acting feminine. Oddly enough, in discussions of Ayesha's femininity, there are little to no critical conversations regarding her beauty, the same way that Lady Audley’s looks are dissected by critics.

\section{Lady Audley's Mix of Accepted Femininity and Masculinity}

A brief note regarding the plot of Lady Audley's Secret: a woman, Lucy Graham, marries Sir Michael Audley. The rest of their small village approves of her except for her nephew, Robert Audley, who takes it upon himself to discover Lady Audley’s past after his friend, George Talboys, goes missing. It turns out that she was once married to George, but he left to seek his fortune in Australia, so she took another husband; when he came back, she attempted to murder him by pushing him down a well. The novel ends with Robert finding career success and love with George’s sister, George returning alive and well, and Lady Audley being sent to a madhouse.

To understand how Lucy Audley encapsulates both espoused values of Victorian masculinity and femininity, we must first understand her nephew, Robert Audley. The pair's stories run parallel, although at the end of the novel, Robert succeeds whilst Lucy dies. I shall first show how Robert Audley ends up representing an ideal Victorian gentleman through his 
synthesis of reason (a masculine trait for the time) and emotion (thought of as a feminine characteristic), and how he is rewarded for such actions. I will then demonstrate how Lucy Audley encapsulates ideas of Victorian femininity while also exercising her reason and independence, as Robert Audley does, although to much different ends.

To understand how Robert Audley functions as a symbol of ideal male prosperity, a brief word is needed about the other two male characters, George Talboys and Sir Michael Audley, and how they are not ideal. Both Sir Michael and George are one-dimensional characters, but for opposing reasons. Sir Michael Audley is too driven by emotion. Of the three gentlemen, he is perhaps what Klein would term the most "feeble"; he comes across as foolish when he asks Lucy Graham to marry him, as Lucy states plainly that she does not love him and even laughs about the fact that she "[does] not love anyone in the entire world" (Braddon 11). However, this does not deter Sir Michael; he acknowledges that he must seem “'a romantic old fool”” and yet proposes again, this time with her consent (11). Armed with the knowledge that this marriage is not one of equal love, Sir Michael is so enamoured with his new wife that he allows himself to be wound around her little finger, remaining a patriarch only in name. Such blind and fervent desires to make Lucy happy symbolise Victorian England's “infatuation with its own creation, the ideal woman” (Schroeder 42). Meanwhile, George Talboys faces the opposite problem: he is, instead, too practical in his interpersonal relationships. When George leaves for Australia, his rationale for leaving make some sense to him: he wishes to make a fortune to support his wife and young son. However, the manner in which he leaves his wife seems heartless and irresponsible, as if he is abandoning his newly-burgeoning family. George recounts how he wrote his wife a note while she slept to explain his absence: ““[I] told her that I had never loved her better than now when I seemed to desert her; that I was going to try my fortune in a new 
world; and that if I succeeded, I should come back to bring her plenty and happiness'” (Braddon 21). While this note does exactly what George intended it to do—notifying his wife that he has gone to seek riches elsewhere-the note itself is impersonal and unfeeling. George's impulse towards practicality ultimately costs him his relationship with his wife and nearly causes his death when Lucy Audley (Helen Talboys’s adopted identity) attempts to push him down a well. Although George means well, his methods are too practical. George's diminished role in the story reinforces this fact, acting more as a plot point by spurring Robert Audley's search, with limited active interaction with Robert or Lucy.

Robert Audley does not fall into either category. He is not overly emotional, as is Sir Michael, yet he is not rational enough to forget the importance of emotion, as George does. Instead, Robert successfully synthesises both emotion and rationality to become the example of a fine Victorian gentleman. His emotion becomes an integral part of his search for George, and motivates him to do something with his life. When Braddon introduces us to Robert, he is described as one who is "supposed to be a barrister," although he bums off his $£ 400$-a-year fortune instead of doing actual work (Braddon 32). He cares little for his family or future, living for personal pleasure rather than attempting to make a better life and a name for himself. He is oblivious to certain emotional nuances, including how his cousin Alicia is in love with him; he ignores her hints and tells her to go after other men, never realising he is the one she wants (125).

However, Robert's friendship with George saves him from becoming an automaton; he ends up caring deeply for George, a care which motivates him to achieve justice for his friend, whom he thinks has been murdered. His worry permeates every aspect of his life. Robert remarks that he has "never eaten a good dinner at this table since I lost George Talboys” (151). His use of "I" turns George’s disappearance from a non-affecting event into a personal one: his 
loss of George is what will change him into a good gentleman. Although this sudden, strong rush of emotion surprises Robert, to the point where it sounds like he is almost in love“flurried and anxious" in his thought processes and alarmed that he "could possibly feel a strong attachment to any creature breathing” (82)—-he does not fight it. Instead, Robert embraces this emotional side and allows it to motivate him, refusing to rest until he discovers the truth. As he states melodramatically, “Justice to the dead first . . . mercy to the living afterwards”” (158). His emotions fuel his sense of duty, a value much esteemed by Victorian gentlemen, and so he begins to act as a gentleman. He becomes responsible, taking control of the investigation so he may serve justice to the supposed dead and honour George’s memory.

Yet Robert is not necessarily melodramatic with his investigation; rather, he uses his reason and intellect in order to solve the mystery and find his (wo)man. He successfully deduces George’s attempted murderer by analysing a specific set of clues, mostly connected to Lady Audley and her past identity as Helen Talboys. He constructs a timeline of Helen Talboys's lastknown appearance, which ends mysteriously with the appearance of Lucy Graham’s arrival near Audley Court (250). Meanwhile, he also uncovers evidence that Helen Talboys’s handwriting mirrors Lucy Audley’s, corroborating his suspicions that the two women are the same. While Robert confides in Clara Talboys, his future wife, that the "'chain of circumstantial evidence”" he has found “ "is formed of very slight links"” (259)—and is thus only one interpretation of the facts he has tracked down-his reading of the facts is so precise that he can come to only one logical conclusion. Robert's deductions are not from random, wild guesses: they come from calculated and precise actions. While he remains guided by his intuition and inner sense of “duty” towards his friend, his thought processes are entirely rational—positioning him as a truly masculine Victorian male. 
This combination of rationality and emotion not only allow Robert to solve the mystery of his missing friend, but also posit him in a position of power at the end of the novel. In the final chapter, “At Peace,” Robert is not only a responsible gentleman, but is described as "a rising man upon the home circuit ... and has convulsed the Court by his deliciously comic rendering of ... amatory correspondence” (Braddon 445). This sentence captures the mix of reason and emotion that Robert seems to have perfectly balanced: he is now well-esteemed in a proper profession, one that involves rational thinking and reasoning to prepare a convincing argument for the court. At the same time, Robert is able to turn these cases from dry, dull affairs into comedic ones. The way that he manages to "convulse the Court" shows how, through injecting humour and feeling into his work, he wins over the higher members of the Court and, by extension, the approval of society. Robert's newfound balance between the two traits—one normally considered feminine, the other masculine—allows him to emerge as a fuller, productive member of society. Robert's victory over Lady Audley symbolises a new patriarchal order, one that views emotion in conjunction with reason as necessary to lead a successful life. Of the three male characters, Robert comes out on top at the end with a successful career and a burgeoning family. George Talboys reappears, injured but alive, yet finds himself living with his sister, Robert's wife, in a regression from his initial introduction as a rich profiteer returning from Australia. Meanwhile, Sir Michael Audley ends up alone, widowed from the young wife he once loved, with Audley Court "shut up" as a way to close that dark period of his life (446).

Of course, Lady Audley's Secret is not merely a journey of Robert's self-discovery: it also deals with Lucy Audley’s journey from abandoned wife to attempted murderess, a transformation that shocks the reader. So what about Lady Audley arouses Robert's suspicion in the first place? Part of his suspicion arises from the fact that her beautiful outward, typically 
feminine appearances do not match up with her assertive actions and desire for self-preservation. On the surface, Lucy Audley appears to be a symbol of perfect Victorian femininity, an ideal wife that any husband would be pleased to have. Her beauty is constantly remarked upon throughout the text, setting her apart from other women with her power to "charm with a word or intoxicate with a smile" (Braddon 6). She is conventionally beautiful, blessed with "flaxen curls" and "soft blue eyes" (6) that enchant nearly everyone who meets her. Her beauty is comparable to that of a Pre-Raphaelite model, a beauty which has undertones of threateningly potent sexuality; when a portrait of her is unveiled at Audley Court, the narrator spares no details in describing how the painting captures her curls with "every glimmer of gold, and every shadow of pale brown" while also making her "deep blue eyes" appear almost "strange ... and sinister" (70). Lucy's breathtaking beauty appears to lull people into a sense of false calm about her; nobody would ever dream of her attempting to act outside her prescribed role in society as Michael Audley's wife because she plays the part so successfully. Who could ever believe such a beautiful woman could attempt to do anything wrong?

Lady Audley also plays into male fantasies of Victorian femininity by acting in a childlike manner, although it is shown that she is perfectly capable of reasoning and thinking for herself. Braddon describes Lady Audley as having “childish lips” (57) and as looking like a "wax doll” (56), giving the impression that Lucy is a toy to be played with by the men that surround her. Lucy is presented as an innocent child-bride, beautiful, naive, and in need of male guidance to have a successful life. The wide age gap between Lucy and her husband also plays Lucy's projected innocent image: she is able to act more like a child because her husband becomes a parental figure (Schroeder 42). Her beauty is simultaneously alluring and childlike, and even her former husband, George, refers to her as “'my little girl,"” an endearment that sounds more 
parental than romantic (Langland 11). As children need care and love from their parents, so child-brides need the same sort of attention from their husbands. Indeed, Lucy does receive this sort of attention: Sir Michael Audley refuses to listen to a bad word against his wife, and defends her against those who see through her childish behaviour. For example, when Sir Michael's daughter, Alicia, complains about the cruel things Lucy has apparently done to her dog, Sir Michael retorts with “'your dog shall be shot ... if his vicious temper ever endangers Lucy’” (103). Instead of trusting Alicia’s gut reaction— that Lucy hides more than she reveals—Sir Michael ensures that he will go to any lengths to preserve his marriage with Lucy, even if it means sacrificing his daughter's happiness. Although Lady Audley clearly holds the power in her relationship with Sir Michael, being the one who is loved rather than the lover, she plays up her role as wife and appears to enjoy her marriage, even if she does not love Sir Michael. She appears as an actively devoted wife: even if he knows that she cannot fully reciprocate his affections, she does her best to make him happy and to cheer him, providing some joy in their marriage.

But Lucy’s looks and childlike behaviour are not all that define her as a character. Lucy manages to reinvent herself in order to escape poverty, working independently to secure a better future for herself. Yet this is the odd thing about Lady Audley's situation by the end of the novel: she seems to have acted in a manner similar to Robert's, and yet ultimately ends up punished for some of the same actions. The set of dire circumstances she rises from from are not of her own doing, but are due to both George and her father's selfish actions. When she finds herself all alone with a son to support, what else can she feasibly do but try to make her own way in life in whatever manner she can? When a modern reader takes these circumstances into account, it becomes obvious that Lady Audley did the best she could in order to save herself from an 
undesirable future. Her Machiavellian techniques are born out of necessity. Her ascent from poverty into riches—and into the arms of another man—is both rationally and emotionally motivated. She no longer wishes to live in fear of the poorhouse and also craves emotional security after having been seemingly abandoned by her husband. Granted, the feeling of security she longs for does not deal with love after George leaves; Lady Audley claims that she feels bitter because her once-rich husband had suddenly destined her “"to beggary and obscurity”" as a “'slave”" who must toil for a paltry living, rather than being supported by a respectable husband (Braddon 353). Lady Audley does not seem to become a full woman in the same way that Robert becomes a full man through this conjunction of reason and emotion. Rather, she is termed “dangerous" by an educated doctor—who represents society as a whole—-because she knows exactly what she has done (379). What makes Lady Audley so dangerous to Victorian readers is this combination of reason and emotion, masculinity and femininity—since she does not fit comfortably in one category or the other, she must be punished.

Lucy's actions spring out of a desire for self-preservation, attempting to survive in whatever manner she can. Motivated to stay off the streets and out of poverty, Lucy must live off her wits if she is to ever succeed. This theme reoccurs not only in her relationship with Sir Michael, but also with her reasons for attempting to kill George and the fire she sets in an attempt to kill Robert. Lucy describes feeling “"tormented”” by both George and Robert (Braddon 275), in part because both of these men remind her of the life she thought she had left behind: George as her former husband, and Robert for digging up so much information and planning to release it. Robert could easily expose Lucy's actions with one or two words and put her back where she began, in poverty with little way to make money or advance in society. Although it is described as an irrational act, to Lucy, her attempt to kill George makes sense 
because she wants to erase any evidence of her former life that could come back to haunt her and destroy her happiness, although it is obviously a little more emotional than she lets on. Later on, Lucy begins to worry that if any of this evidence is released, she will have to go back to " "the old, hard, cruel, wretched life--the life of poverty, and humiliation, and vexation, and discontent'” (316) before resolving that she will not let this happen to her. Her burning of the Castle Inn and her desire to rid herself, literally, of Robert Audley mirrors her wish to metaphorically burn away any connections she might have to her past, excising her previous identity as Helen Talboys so she will not be forced into poverty ever again.

Lucy does exactly as George and Robert do in attempting to reinvent herself, yet it is viewed as a negative action, something that women of the time were not meant to do. While George and Robert obviously have the freedom to remake themselves in Victorian society for the better, Lucy does not have the same luxury, even though she takes a similar route. As the Schroeders point out, Lucy approaches husband-hunting as a "vocation" (30), taking it as seriously as the men take their own livelihoods. It is also worth pointing out that Lucy does not come to the conclusion to find a new husband in an over-emotional fit: her decision to leave her old life as Helen Talboys and to adopt the name Lucy Graham is presented as an entirely rational and sane decision for her to make. As her former landlady remembers, Helen “"tried to support herself after her husband's desertion by giving music lessons ... [but] her father took her money from her, and spent it in public-houses'” (Braddon 249). Clearly, she struggled to make a living for herself after George left, and yet her money was ciphered away by her father, a failed and drunken patriarch, for his own pursuits. It makes sense that she would eventually come to the conclusion that she could break away from her father's weakening grip in order to make her own way through the world, finally making life better for herself. And yet it seems that this rational, 
perhaps too “masculine” decision, is part of the reason for Lady Audley's ultimate downfall: she exercised her reason and made decisions for herself without necessarily bowing down to a male authority figure. Part of this stems from a gender-based double standard: “for men, self-invention can lead to self-improvement; for women, reinvention implies duplicity and disguise” (Schroeder 36). Lucy's reinvention of self is not seen as positive, but as sly and duplicitous. Lucy appears to be a "bad female" not just because of the masculine implications of her independent actions, but because she is not as innocent and pure as she is initially introduced.

But that on its own is not enough to make Lady Audley into the dangerous Victorian villain that we see on the page. Her ability to stand outside typical Victorian feminine behaviour-deferring and demure--is undermined by the fact that she remains very feminine. Lucy never resorts to any Shakespearean methods of disguise by dressing up as a man, nor does she identify strongly with any sort of feminist movement (and become “mannish” by association). A good number of her actions may come across as typically masculine, but they do not undermine her uber-feminine qualities. It is my belief that Victorian readers could not reconcile both these aspects in one single character, could not believe how a woman could exercise her reason and yet maintain a traditionally feminine appearance to mask such “cunning” simultaneously. As Herbert Klein puts it, "Lady Audley's secret thus seems to be that happiness is to be found in the joined transgression of gender stereotypes” (173).

Perhaps the reason why Lady Audley is punished and why Robert is rewarded is because Lady Audley appears, to Victorian eyes, as a deceptive liar who uses her beauty as a cover. She oversteps the bounds of her class and gender and fights the status quo while attempting to improve her life. Jennifer Hedgecock comments that Lady Audley’s Secret appears to be a comment on this societal double standard, where women are meant to be "good girls" who may 
never lie or disguise themselves, while men are allowed to adopt new identities with ease (124). While it seems appropriate that Lady Audley has a strong emotional response to the way that George Talboys abandoned her—a modern reader sympathises with her plight after hearing her emotional story — the fact that she acts upon her emotions is what takes her from "normal" to “dangerous.” Although she has essentially done the same thing Robert did by using her intuition to guide her towards rational decisions, the decisions she has made are unsound and threatening. Compared with Robert's investigation into her activities, which is very slow in terms of its buildup, it only takes Lady Audley fifteen minutes to push George Talboys down a well in order to begin the whole ordeal. Thus women who are gifted with both reason and emotion within this novel are portrayed as inept and incapable of making good decisions. Meanwhile, modern readers might view Lady Audley as courageous and independent for using all her strength and knowledge in order to survive and outwit the threat of poverty. For a woman attempting to regain her place in society, Lady Audley does quite well, and almost gets away with her plan without hurting anyone in the process.

As E. M. Forster might describe her, Lady Audley is a "round" character instead of a flat, dimensionless character that Victorian writers frequently used. She does not sit around and simper in the background, but has a complex characterisation unusual for a female character at the time, something we as modern readers appreciate. Yet Braddon's novel focuses more on how evil she is as a woman because she does not live up to her exterior appearance. While she appears to be a "blue-eyed wax doll,” a term which implies malleability and being manipulated, Lady Audley's actions turn her into one who actively manipulates, playing with humans as if they were dolls instead of merely acting like one herself. In a way, this notion turns the phrase "women should be seen and not heard" on its head: women can indeed be heard if they are 
discussing their emotions, but if they are seen performing actions that they should not—whether through the exercise of reason or not—-then they automatically become villains. We as modern readers might pity Lady Audley due to her dire circumstances, but for the Victorians, she overstepped too many boundaries to be a truly sympathetic protagonist.

\section{Ayesha as Ahistorical Renaissance Woman}

To examine Ayesha and how her power functions in She, we must first understand Ludwig Horace Holly, the male protagonist, and how his rational worldview represents a vision of Victorian England that contemporary readers were meant to respect and emulate. I will then look at Ayesha herself and how she derives her power from both her feminine and masculine personality traits, mirroring Queen Victoria. However, one must note that Ayesha is not selfmade as Lady Audley is, but is more of a male fantasy brought to life. When she begins acting of her own volition, she must be prevented from taking further action, as fantasies are only meant to remain fantasies, so they may be controlled.

H. Rider Haggard's She posits a rational, masculine world model through the protagonist, Ludwig Horace Holly. Along with his twenty-five-year-old adopted son Leo Vincey and his crotchety butler Job, Holly travels to Africa in order to investigate and destroy the mysterious Ayesha, who is somehow historically linked to the Vincey family. Things become mildly complicated when Ayesha reveals that Leo is the reincarnation of her dead lover, Kallikrates, and attempts to wed him and expand her power, which Holly and Leo must prevent from happening. Holly is a Cambridge scholar who embodies rational and educated thought at the end of the 
nineteenth century. Gifted in mathematics, a concrete discipline as opposed to literature or history, Holly is a sceptic, reluctant to believe in the legend of Ayesha as it is first presented. The stories regarding Kallikrates are shown in various Greek, Latin, and old English manuscripts, languages Holly can ably read and translate, a nod to his level of education. Yet despite the evident history of these documents, Holly states that the legend of a beautiful white woman governing over an African colony is “"balderdash”” (Haggard 31) and that Leo’s father, who wrote to Holly and his son to tell him of the legend, "was [not] quite sane when he wrote that letter” (48). Holly's rigid belief in facts marks him as a respectable and sensible man, especially in an age of phony seances and spiritualism: he does not believe in supernatural forces and seeks out rational explanations, rather than relying on myth or supposedly verified texts. Holly cannot deal with the supernatural Ayesha when he finally meets her, deeming her a "hoax" whilst wondering how he, a man "not unacquainted with the leading scientific facts of our history ... could believe that within the last few minutes I had ... engaged in conversation with a woman two thousand and odd years old" (159). Holly's refusal to believe in "the hocus-pocus which in Europe goes by the name of the supernatural” (159) paints him as a scientific and, thus, trustworthy man. When he finally does concede that Ayesha is a few thousand years old and that her powers are legitimate, we believe him because he goes to great pains to seek out scientific explanations. Like Sherlock Holmes, Holly soon learns that "Whatever remains, however improbable, must be the truth." Holly is not only sceptical about the supernatural, though; he is also highly suspicious of women. Several times throughout the novel, he proudly declares he is a "misogynist” $(88,160)$ and finds this quality admirable in others, including his butler. The way Haggard constructs his story, with his protagonist travelling to Africa intending to destroy a woman, suggests that misogyny should be encouraged in Victorian society: Holly does not do it 
for the gold or glory, nor to claim the land of Kôr in the name of Queen Victoria, but to rid the world of a too-powerful woman.

While Holly's intelligence is a staple of ideal Victorian masculinity, his physical appearance does not match that of the traditional hero. Although She does not answer questions regarding general beauty and ugliness, it does seem to comment upon male freedom in terms of their appearance, compared to a relatively narrow strait that women have. Holly is introduced as a "specimen" of humanity, as if he is an experiment gone wrong rather than a normal human (Haggard 4). He is notably ugly, being “short, rather bow-legged," and reminds the "editor" ${ }^{\text {" of }}$ the work "forcibly of a gorilla" (4), with his "long sinewy arms" and "a low brow half overgrown" (10). In contrast, the dunderheaded Leo is "the Greek god" (4) with "golden curls" (21) and the stature of Apollo (23). As one critic kindly puts it, “although Leo’s physically a virtual embodiment of a beautiful Greek god, his intellectual attributes seem to fall far short of one” (Sindha 36). While physical appearances were commonly used in Victorian literature to denote goodness and purity or moral corruptness—see also Robert Louis Stevenson’s descriptions of the troglodylic and primeval Mr Hyde—-Haggard shows that it is not quite the case with his heroes. It is not to say that Leo is entirely unintelligent or unable to make decisions, but his role in She seems more like a traditional female role-acting as the loyal love interest, Kallikrates, to Ayesha, who promises to do him right. Meanwhile, the emphasis on Holly's ugliness and exceptional intelligence seems to promote the message that appearances did not necessarily matter in true Victorian gentlemen. It might help not to look like one spends their nights sleeping in the streets, but Holly's ugliness never prevents him from doing what he wishes to do, unlike it might a woman. He is never seen as a traitor or a fraud due to his appearances.

\footnotetext{
${ }^{2}$ There is no actual "editor" of She separate from H. Rider Haggard; it is presented as a series of "found manuscripts" that have been pieced together to maintain the illusion of verisimilitude.
} 
Haggard upholds the Victorian double-standard that men are not held back by the way they look, whilst women must be beautiful if they are worthy of attention.

Ayesha is, indeed, devastatingly beautiful, in a conventionally feminine manner. Much emphasis is put upon the mystery of her physical appearance: whilst waiting to meet her, Holly wonders if Ayesha is "some naked savage queen, a languishing Oriental beauty, or a nineteenthcentury young lady, drinking tea” (Haggard 142). Of course, Holly is correct on none of these counts. Ayesha initially appears as a "ghost-like apparition" (142), moving with a "snake-like grace” (143) and with the brightness of a "celestial being” (156), descriptors that imply a supernatural or inhuman quality to Ayesha. She is too beautiful that Holly cannot use normal descriptors such as "fair" or "handsome," and must thus resort to more extreme comparisons. Several times Holly compares her to various gods and mythic figures, including Venus (226), Galatea (226), and Aphrodite (190). Great emphasis is put upon Ayesha's veil and how she is swathed in "long, corpse-like wrappings" (156), suggesting that a great deal of her power comes from hiding and masking her beauty. The veil also recalls Victorian fashion trends, when women would veil their faces for modesty, keeping their faces masked and mysterious to increase the allure and power of their beauty. In this sense, Ayesha’s beauty becomes recognisably powerful to Victorian females, as they find the same sort of masking in their own culture. At the same time, Ayesha’s beauty fulfills a number of European male fantasies. She is "white as snow” with "the pinkest nails" (142), thus reinforcing Eurocentric ideas that fair skin is the most desired for beauty, yet Ayesha states that she is “"Arabian [by] birth ... [and a true] Arab of the Arabs”" (147). She is both at once the pinnacle of classical European beauty standards and yet is also an Eastern, exotic beauty, one that explorers such as Holly and Leo can justify conquering due to her foreignness. 
It is important to note the source of Ayesha's alluring youthful looks, obtained through eternal life, is through men. Through beguiling a hermit with her beauty, Ayesha was " "told the secrets of the Fire [of Life]'” and used it to ensure her own immortality (Haggard 277). It would be one thing if Ayesha discovered the Fire by herself, but the fact that she gained the knowledge from a wise man seems significant: her beauty is not self-made, like Lady Audley's looks, which help to ease her passage through society, but is man-made and thus not hers to own. In this manner, Ayesha becomes the sort of fulfillment of a male fantasy, her eternal beauty and youth in part bestowed upon her by a man. The point about fantasies, though, is that they are meant to stay fantasies so they can be controlled by whoever created them--a point which I shall return to later.

In addition to her beauty, Ayesha fulfills other Victorian stereotypes regarding women through her unabashed displays of intense emotion, although not necessarily through swooning and fainting over those she loves. When she is angry, she refuses to remain silent, and curses out whoever has wronged her. For example, Ayesha unleashes a litany of jealous curses, including “"Curse her, the daughter of the Nile, because of her beauty”" and "“Curse her, because her magic hath prevailed against me'” when she discovers that a local Amahaggar woman has become attached to Leo, who Ayesha believes is Kallikrates (Haggard 164). This behaviour plays into negative Victorian stereotypes of women as emotional and jealous beings. While these sentiments do not play into the subservient and docile "Angel of the House" image, Victorian readers would still have accepted Ayesha's overemotional reactions as a feminine trait, an indication that women were always too irrational.

Ayesha also acts in a conventionally accepted feminine manner in the way she treats Kallikrates. Rather than taking a new lover or acting promiscuously, Ayesha's undying love and 
fidelity to her dead lover, now evidently reincarnated in Leo, sets her apart. In the Amahaggar's matrilineal society, women have the power to choose their spouses: in the case of the ruling house, the Queen waits for a female heir to be born, and then sends the husband to be put to death (Haggard 91). As powerful as she is, Ayesha could take any number of husbands or lovers as she wishes, yet pines only for her Kallikrates: “"to have lived two thousand years, with all my passion eating at my heart, and with my sin ever before me!'” (166). Ayesha’s behaviour parallels that of Queen Victoria after her husband Albert died in 1861: she remained in mourning for the next forty years, refusing to allow Albert to die from her memory. Gerald Monsman argues that Ayesha's love is "feminine” and "ideal” for male Victorian audiences, representing Platonic ideals of love that are pure and unblemished (196). Ayesha clearly shows remorse for having killed Kallikrates some two thousand years previously and remains emotionally distraught for her past actions. When she weeps, Holly states that "there was something so horrible about the sight of this awe-inspiring woman letting loose her passion on the dead ... that I could no longer bear to look at it” (167). Ayesha's emotional response is not only acceptable in its own right— to a male Victorian mind, a woman should react so emotionally to her lover's death—but is powerful in itself, awing Holly with its power. It is an acceptable power, however: this is one instance of Ayesha not "pursu[ing] power as men pursued power" (Etherington 86). She can have powerful emotions as long as she does not trespass over traditionally-held male territory.

But, of course, Ayesha does trespass over said territory. She is far more powerful than the typical Victorian woman due to her combination of feminine and masculine traits. As Holly puts it, "I am but a man, and she was more than a woman" (Haggard 191, emphasis mine). Ayesha is not only a beautiful, devoted lover, but she is also intelligent and learned: "the natural scientist 
and historian in Holly find their match in this ageless woman” (Sinha 38). Instead of being trained in feminine arts such as botany, embroidery, and music, Ayesha is versed in history and science just as much as Holly and Leo are. Holly notes that Ayesha is "a great chemist" and that, while her passion for chemistry appears as an "amusement," she manages to attain "sufficiently surprising” results (194). Indeed, it is surprising that a woman performs chemistry in a Victorian novel without fainting over the fumes. With Ayesha's high level of intelligence also comes the ability to think rationally, with knowledge holding sway instead of emotions. As with Holly, Haggard emphasises Ayesha's rationality. She states repeatedly that "'there is no such thing is magic'” (152; 194) and does not seem to hold any supernatural beliefs. Although the events of She are clearly supernatural—surely nobody in 1887 had discovered the secret to immortality— Ayesha's rationality lends credibility to both the way she lives and also her story at large, the way that Greek and Latin texts at the beginning of the story lend credence to the de Vincey legend.

Not only is Ayesha gifted with a classical education that middle-class Victorian men would have had, but her knowledge extends to matters that Victorian men attempted to masterthings a good Victorian woman would have no business knowing. Ayesha claims to have “"knowledge of the hidden ways of Nature” (152), most notably mastery over Death: a much different, darker version of nature than the Victorians were used to. While a man gave Ayesha the secret of youth, he did not necessarily force it upon her: Ayesha remembers that the hermit died with “'all life at his command,” yet refused to use it out of good conscience (278). Ayesha made the decision herself to jump into the flame, showing authority and volition over her fate. In a way, Ayesha plays god with her fate, extending her life beyond that of a normal lifespan. Not only does her immorality give an indication as to how much power Ayesha can truly wield, but 
also mirror Victorian explorers' and scientists' goals at the time. The Victorian era was one of conquest, with men trying to take countries in the Queen's name, harnessing scientific techniques to create medical breakthroughs, and attempting to control natives in order to spread British ideas and make the natives less “savage.” This is clearly Holly and Leo’s goal as they traipse through the Amahaggar colony: the number of times they refer to the Amahaggar as "savages" or "barbarians" is nearly uncountable, and shows that the Amahaggar must be tamed and brought into line with Victorian values.

Ayesha's power is not limited to controlling her fellow Amahaggar, however. Her dreams of world domination serve as an outright threat to the ruling Victorian patriarchy. Patricia Murphy argues that Ayesha poses a threat to Leo and Holly as Victorian explorers because she is "ahistorical" and seems to reside outside of conventional, cause-and-effect depictions of history that the Victorians thrived upon (“Gendering” 757). Ayesha seems out-of-touch with contemporary knowledge of history, asking at one point if Greece still exists while trying to determine how the world has changed during her millennia-long Kôr. To be honest, we never have a clear idea of how her reign came to be: we know she has an "empire of the imagination" and rules by fear, but we do not know why she possesses or pursues power, other than the simple reason that she can (Haggard 177). It seems as if Ayesha wants to make her mark in history and set forth her own lineage, spreading her matriarchal rule to patriarchal societies. According to Murphy, history in She is gendered as male, and must be carried forth by men such as Holly and Leo, in order to preserve Victorian notions of stability (749). It goes without saying that historically, political power has also been gendered as male, and Ayesha transgresses this boundary when she states her desires to take over England with Leo/Kallikrates. Ayesha claims 
that she is “'above the law”" and can act as she likes, including attempting to spread her rule worldwide (Haggard 253).

While her threat of spreading her power is enough to make Holly and Leo nervous, it is also worth nothing that her statement of being "above the law" applies to the legal position of women in Victorian England. As mentioned before, women had hardly any legal rights at the beginning of Victoria’s reign, and were only slowly beginning to gain more traction. Women were not allowed to control their own property until the Married Women’s Act of 1882 and had to jump through all sorts of legal loopholes in order to divorce their husbands. Meanwhile, men could circumvent these laws merely due to their gender. In this case, Ayesha views herself as powerful, if not more so, as any Victorian man, above Victorian social codes and laws. She has wishes and desires and intends to follow through with them, seeking power as a man might, thus leading to Holly and Leo's anxiety. What is more, Holly acknowledges that Ayesha would be a strong and powerful leader, even if her strategy was dangerous: "I had little doubt ... she would speedily make ours the most glorious and prosperous empire the world has ever seen” (Haggard 254). For all Holly's claims that he is a vehement misogynist, he does think that she would make as good a leader of Britain as Victoria herself. What is important about Ayesha’s desire (and subsequent actions) to take over the world is that it is one of the few times we see her acting for herself, not just passively enjoying the power she already has. Nobody feeds the idea to Ayesha: it is all her own and she takes active steps towards attempting to secure this power. Her marriage to Kallikrates will ensure that she has a suitable consort, and after their marriage and subsequent foray into the Fire to reaffirm their immortality, the couple will be able to rule the world. While her desire to rule does appear to be spurred by Kallikrates’ reappearance and she wishes for them 
to be together, it is clear that Ayesha will be the one doing the ruling and the couple will not rest on an equal footing.

Yet it seems that Ayesha is too much of all of these traits. Because she does not comfortably sit in the binary of traditional masculine behaviour or traditional feminine behaviour, she is doomed to fail. In trying to have it all, Ayesha becomes greedy and must fall. Her second foray into the eternal flame of Kôr at the end of the novel seems like a power grab: she wishes to maintain her beautiful looks and life (a feminine demand) in order to achieve her goals of ruling over the world (a masculine desire). In doing so, Ayesha is not allowed to have either because she is playing God as a woman. Holly and Leo, along with other male English explorers, are allowed "immortality" of a sort due to their various travels around Africa; they return back to England in one piece and write an account of their adventures, so their names will live on in association with Kôr as the men who defeated She-Who-Must-Be-Obeyed. They do not revert back to primitive states, as Ayesha does in the fire: she turns into a "monkey" and a “big ape” as she loses her youth, slowly disintegrating before Holly and Leo’s eyes (Haggard 291-92). In one move, Ayesha loses her beauty and her life, ensuring she will never become the ruler she wishes to be. She has dabbled in matters she should not—she should not have attempted to expand her rule outside of her small corner of the world—and must thus be neutralised, prevented from spreading her threat around the world.

Through her actions at the flame and also her desire to gain more power, Ayesha begins to step out of her initial role as a male fantasy come to life. Ayesha never needed to survive the way Lady Audley did: poverty was never an option for her, as western ideas of wealth were not part of Amahaggar society. But the way that Ayesha attempts to move towards spreading her power means that she is moving outside of male control. Ayesha begins to enter into a position 
where she refuses to be controlled by anyone, least of all the men who created her. Hence she must be destroyed. Unlike Lady Audley, Ayesha is not seen as disingenuous about what she wants to do: she is upfront with her demands and does not put on a face for a particular crowd whilst working behind their backs. But Ayesha and Lucy Audley share the same sort of sincerity of intent behind their actions. Lucy plays up her femininity as an act of self-preservation, so that she will not end up destitute and in poverty once more, whilst Ayesha pursues power outside of Kôr as one of the first independent actions she is able to do in her reign. Her desire for power is not a mere power-grab for attention, but an assertion of her power beyond the confines of the Amahaggar community and some of the constraints set up by the men that surround her.

\section{Conclusion}

As I have demonstrated, both Lady Audley and Ayesha have a combination of typically masculine and feminine traits that affect the way they are perceived by Victorian men, leading to their eventual "tamings" at the end of each of their narratives. Both do not shun or outwardly subvert ideals held of Victorian femininity: both are extremely conventionally beautiful, and show some level of dedication to their families or lovers. Yet both women also act assertively and independently, attempting to use their power either to overcome adverse situations or to legitimise already-held power on her own terms. The ultimate question for modern readers, though, is so what? Why should we care about these two Victorian texts and what they say about gender ideals of the nineteenth century?

Simply put, I think these two texts deserve attention because they were incredibly popular and influential. They may not be canonical texts in the sense that they are treated with the same reverence of the works of the Brontë sisters or Charles Dickens, but both texts were immensely 
popular upon publication. Lady Audley’s Secret, serialised in the early 1860s, quickly made Mary Elizabeth Braddon’s career and caused an uproar with its references to adultery and murder, as well as the unconventional notion that "a conventionally attractive woman could be presented with a satisfying depth and complexity of character" (Skilton xviii). Likewise, She was serialised in the late 1880s and remained influential, with authors from J. R. R. Tolkien to C. S. Lewis to and Margaret Atwood citing the influence of She upon their own fiction (Atwood xxiii). Granted, just because a work is popular does not necessarily mean it is well-written or objectively “good”: Stephenie Meyer's Twilight is full of clunky prose and features questionable representations of women, but that never stopped it from becoming a cultural phenomenon, one worth studying if only to discover its effects upon those who read it. Braddon and Haggard, it must be said, are not the best writers in the world, let alone the Victorian age. Even though many passages in their novels are mediocre, both were masters of pacing and plot, cultivating massive followings. Their works became influential upon Victorian readers, which is especially interesting to think about in terms of gender: if they were so popular, then did they create these female characters to show women how they should act in real life?

I argue that yes, these characters are meant to show women how they should (or should not) go about their lives. Lucy Audley’s adoption of a new identity and actions are decried as criminal and not to be emulated, showing that women with too much authority will use it for worse and deserve to be punished. Meanwhile, Ayesha's death in She serves as a warning to the "New Woman who might be tempted to demonstrate a degree of sexual authority, enlarge the scope of her educational or political ambitions, or demand visibility in the public sphere" (Libby 12). If the Victorian reading public, both men and women, found themselves continually subjected to depictions of women who overstep gender boundaries somehow and end up dead 
because of it, then these men and women might internalise these notions of gender and attempt to regulate them or enact them in real life. Granted, both Lady Audley and Ayesha live extreme lives due to the sensational and fantastical aspects of their stories--very few people find themselves covering up a murder of their spouse or travelling to the middle of Africa to find a two-thousand-year-old woman. Still, the overarching message of both these books remain potent: if you act in ways that society does not encourage, you will be punished for your actions. Women may have been frustrated with the Angel of the House, but how could they fight her when she was so safe, guaranteed to make their lives easier instead of facing chastisement (or worse) for attempting to carve out their own paths? Unwritten social rules and societal gatherings were, indeed, crucial in maintaining gender performance norms and deeming how women could or could not act, but with a growing reading public and easier access to books, the importance of fiction cannot be overstated. Women no longer received advice on behaviour only through etiquette handbooks, but also through stories that simultaneously entertained and enforced gender boundaries. Studying texts as popular as these allow us to think of what their impact might have been upon the reading public. Men learnt, through consuming books such as these, that women who spoke out or rebelled against typical femininity were dangerous and needed to be controlled, while women learnt that they should stick to their prescribed roles. It is so easy for scholars or even casual readers to write off popular novels as unworthy of attention, but when enough people read a book and begin to enact its messages, for better or worse, it is time to stop criticising the work and instead to begin examining it, learning what it says about this time in history.

\section{Works Cited}

Atwood, Margaret. Introduction. She: A History of Adventure. By H. Rider Haggard. 1887. New York: Random House, 2002. xvii-xxiv. Print. 
Braddon, Mary Elizabeth. Lady Audley’s Secret. Ed. David Skilton. Oxford: Oxford UP, 1998. Print.

Christ, Carol T., and Catherine Robson, eds. The Victorian Age. Norton: New York, 2006. Print.

Haggard, H. Rider. The Annotated She. Ed. Norman Etherington. Bloomington: Indiana UP, 1991. Print.

Hedgecock, Jennifer. The Femme Fatale in Victorian Literature. Amherst, NY: Cambria, 2008. Print.

Klein, Herbert G. "Strong Women and Feeble Men: Upsetting Gender Stereotypes in Mary Elizabeth Braddon's Lady Audley's Secret.” Atenea 28.1 (2008): 161-174. Web. 27 Aug. 2012.

Langland, Elizabeth. “Enclosure Acts: Framing Women’s Bodies in Braddon's Lady Audley’s Secret.” Beyond Sensation: Mary Elizabeth Braddon in Context. Eds. Marlene Tromp, Pamela K. Gilbert, and Aeron Hayne. Albany: SUNY UP, 2000. Print.

Libby, Andrew. "Revisiting the Sublime: Terrible Women and the Aesthetics of Misogyny in H. Rider Haggard's King Solomon's Mines and She." CEA Critic: An Official Journal of the College English Association 67.1 (2004): 1-14. Web. 22 Aug. 2012.

Monsman, Gerald. H. Rider Haggard on the Imperial Frontier: The Political and Literary Contexts of His African Romances. Greensboro, NC: ELT Press, 2006. Print.

Murphy, Patricia. Time Is of the Essence: Temporality, Gender, and the New Woman. Albany, NY: SUNY UP, 2001. Print.

-----. “The Gendering of History in She.” SEL Studies in Literature 1500-1900 39.4 (1999): 747772. Web. 25 Aug. 2012.

Patmore, Coventry. “The Angel in the House.” Christ and Robson 1585-87. Print.

Picard, Liza. Victorian London. London: Phoenix, 2005. Print.

Pykett, Lyn. The 'Improper' Feminine: The Women's Sensation Novel and the New Woman Writing. New York: Routledge, 1992. Print.

Rowbotham, Judith. Good Girls Make Good Wives: Guidance for Girls in Victorian Fiction. Oxford: Basil Blackwell, 1989. Print.

Schroeder, Natalie and Ronald A. Schroeder. From Sensation to Society: Representations of Marriage in the Fiction of Mary Elizabeth Braddon, 1862-1866. Newark: U of Delaware P, 2006. Print.

Sindha, Madhudaya. "Triangular Erotics: The Politics of Masculinity, Imperialism, and BigGame Hunting in Rider Haggard’s She.” Critical Survey 20.3 (2008): 29-43. Web. 14 Sept. 2012.

Stickney Ellis, Sarah. “Disinterested Kindness.” Christ and Robson 1584-85. Print. 